\title{
The manca stages of Porcellio dilatatus Brandt (Crustacea, Isopoda, Oniscidea)
}

\author{
Pedro E. D. Brum ${ }^{1} \&$ Paula B. Araujo ${ }^{2}$
}

Departamento de Zoologia, Instituto de Biociências, Universidade Federal do Rio Grande do Sul. 91509-900 Porto Alegre, Rio Grande do Sul, Brasil. E-mail: pepe_bioufrgs@yahoo.com.br; pbaraujo@portoweb.com.br

\begin{abstract}
This paper presents the description of the three manca stages of the terrestrial isopod Porcellio dilatatus Brandt, 1833 (Porcellionidae). Ovigerous females were collected and kept in the laboratory under controlled conditions $\left(23^{\circ} \mathrm{C} \pm 1{ }^{\circ} \mathrm{C}\right.$ and $14: 10 \mathrm{~h}$ light:darkness). After birth, mancas $(\mathrm{M})$ were individually reared, and their development was observed. Stages M I, M II, and M III were described based on general characteristics, ommatidia, and appendages. The average development time of each stage was: $\mathrm{M} \mathrm{I}=18.7 \pm 1.5 \mathrm{~h}(\mathrm{n}=52)$, M II $=12.7 \pm 1.19$ days $(n=101)$, and $M$ III $=12.7 \pm 0.45$ days $(n=24)$. Growth was observed using measurements of cephalotorax width. The main characteristics of each stage are presented.
\end{abstract}

KEY WORDS. Morphology; post-marsupial development; terrestrial isopod.

RESUMO. Os estágios de manca de Porcellio dilatatus Brandt (Crustacea, Isopoda, Oniscidea). Este trabalho apresenta a descrição dos três estágios de manca $(\mathrm{M})$ do isópodo terrestre Porcellio dilatatus Brandt,1833 (Porcellionidae). Fêmeas ovígeras foram coletadas e mantidas em laboratório sob condições controladas $\left(23^{\circ} \mathrm{C} \pm\right.$ $1^{\circ} \mathrm{C}$ e 14:10 h luz:escuro). Ao saírem do marsúpio as mancas (M) foram criadas individualmente e o seu desenvolvimento foi observado. Os estágios M I, M II, e M III foram descritos com base em caracteres gerais, ommatidia, e apêndices. $O$ tempo médio de desenvolvimento para cada estágio foi: $\mathrm{MI}=18,7 \pm 1,5 \mathrm{~h}(\mathrm{n}=52), \mathrm{M}$ II $=12,7$ $\pm 1,19$ dias $(\mathrm{n}=101)$, e $\mathrm{M}$ III = 12,7 $\pm 0,45$ dias $(\mathrm{n}=24)$. O crescimento foi observado utilizando a medida da largura do cefalotórax. São apresentadas as características principais de cada estágio.

PALAVRAS-CHAVE. Desenvolvimento pós-marsupial; isópodo terrestre; morfologia.

Including about 3600 species (SCHMALfuss 2003), terrestrial isopods are crustaceans adapted to life on land, exhibiting morphological, physiological and behavioral adaptations. They present direct development, with the eggs developing inside the marsupium, where they hatch as mancas, and where they remain for a short period (Hoese \& JANSSEN 1989). The marsupium functions as a micro-aquarium that allows embryonic development to occur without an external water source (HoEsE 1984). Hoese \& JANSSEN (1989) demonstrated that in higher Oniscidea possessing a terrestrial type of marsupium the brood is actively nourished by the mother through the cotyledons. At the time the youngs leave the marsupium, their appearance is similar to that of adults, but they lack the seventh pair of pereiopods, and are classified as manca I (M I) (Araujo et al. 2004). They undergo progressive molts of manca stages, two in general, until the complete development of the seventh pair of pereiopods and the beginning of the development of secondary sexual characteristics. At this time, they are classified as juveniles (Araujo et al. 2004).

Calcium deposits on thoracic sternites indicate the premolt period (ZIDAR et al. 1998). Although the exact moment of ecdysis may not be observed, the passage for the next stage can be verified by the presence of exuvia in the gut they ingest after molting (ARAujo et al. 2004).
Several studies on the post-marsupial development in terrestrial isopods were conducted (Verhoeff 1920, Heeley 1941, Vandel 1943, Matsakis 1955, Haddad 1982, Tomescu \& Craciun 1987, Kacem-Lachkar 1997, Araujo et al. 2004), but few present detailed information on the manca stages. Heeley (1941) described the initial stages of the development in some Oniscidea, where he included Porcellio dilatatus Brandt, 1833, providing a brief description of the mancas.

Introduced in many parts of the world (Schmalfuss 2003), $P$. dilatatus is generally found in synanthropic environments (HopкIN 1991), occurring in sympatry with native species of other terrestrial isopods. In Brazil, it is recorded in the States: Minas Gerais, Rio de Janeiro, São Paulo, Paraná, Santa Catarina, and Rio Grande do Sul (Lemos de Castro 1971, Araujo et al. 1996).

This study presents the description of the manca stages of $P$. dilatatus, extending the knowledge on the post-marsupial development in terrestrial isopods.

\section{MATERIAL AND METHODS}

Ovigerous females of $P$. dilatatus were collected in the State of Rio Grande do Sul, in a park of the city of Porto Alegre $\left(30^{\circ} 02^{\prime} 15^{\prime \prime} \mathrm{S}, 51^{\circ} 13^{\prime} 13^{\prime \prime} \mathrm{W}\right)$ and in an area where eucalyptus pre-

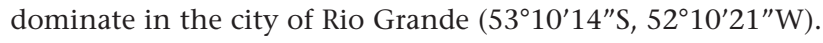
Animals were individually placed in plastic recipient (6- $\mathrm{cm}$ high

Revista Brasileira de Zoologia 24 (2): 493-502, junho 2007 


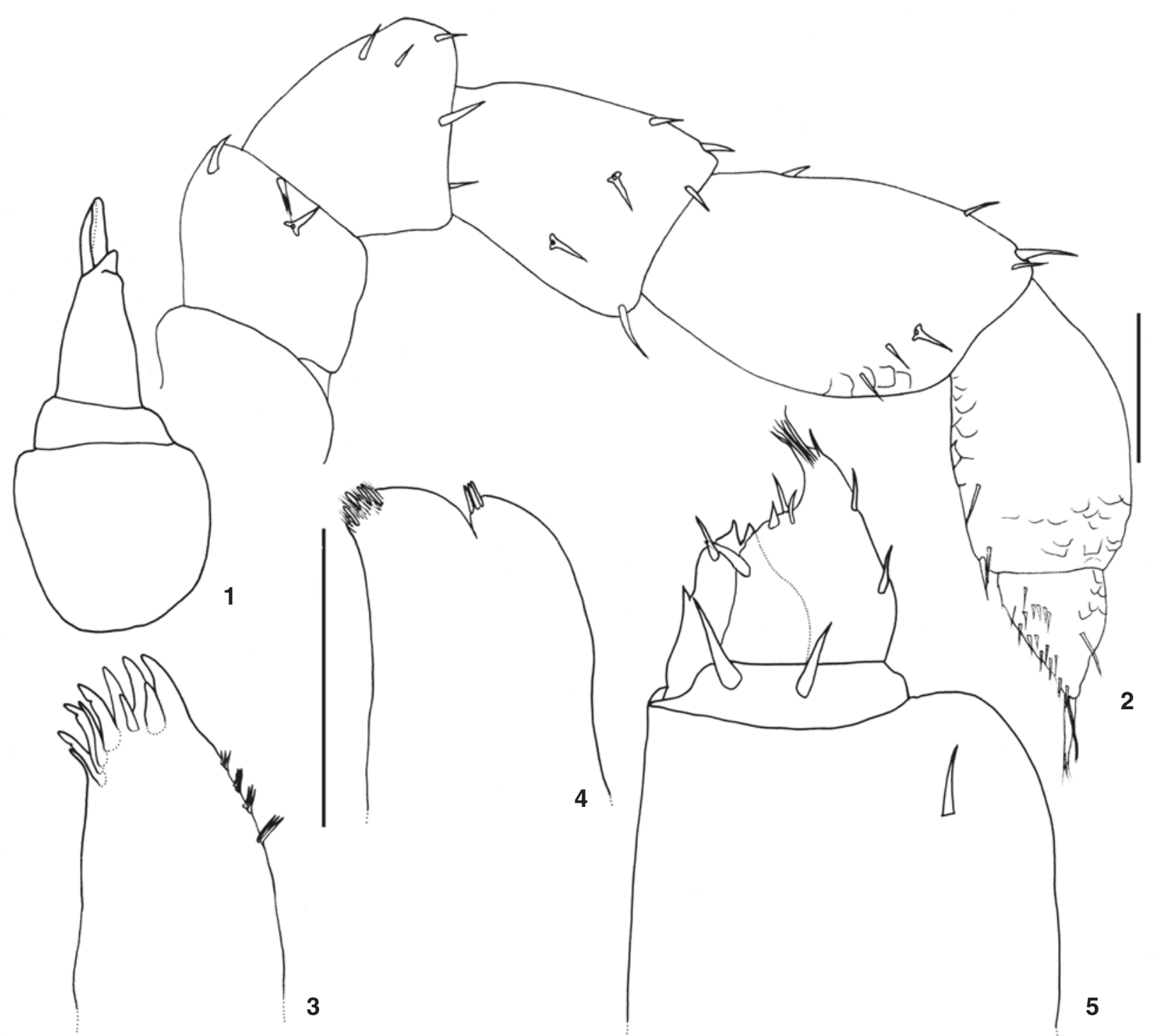

Figures 1-5. Porcellio dilatatus manca I: (1) antennula; (2) antenna; (3) maxillula; (4) maxilla; (5) maxilliped. Scales: 1, 3-5 = 0.1 mm; $2=0.1 \mathrm{~mm}$.

by 6-cm wide) containing a damp piece of filter paper and some cotton to maintain humidity. Litter from the sampling area was offered as food, as well as adult feces, as these are nutrient sources (Helden \& Hassall 1998) and contain microorganisms that may help to balance gut pH (Zimmer \& Topp 1998). A thin soil layer was added to allow mancas' previously observed burrowing behavior. Animals were kept at a constant temperature of $23 \pm 1^{\circ} \mathrm{C}$ and photoperiod 14:10 h light: darkness.

Females were daily observed in order to register the moment when mancas crawl out of the marsupium. The development time of each manca stage was observed using calcium plates (ZiDAR et al. 1998) or exuvia in the gut (Araujo et al. 2004).
During development, individuals representative of each stage were fixed in ethanol $70^{\circ}$ GL for description ( $n=15$ for each stage) and measurements. The dissected animals were examined under the microscope, and drawn with the aid of a camera lucida (Olympus CX31). SEM preparations were performed according to LeIsTIKow \& ARAujo (2001), and coated with gold at Centro de Microscopia Eletrônica, UFRGS (CME). Cephalothorax width $(\mathrm{CW})$ was used as an indication of size (Araujo et al. 2004). It corresponds to the largest width in a dorsal view on a horizontal plane, at eye level.

Information from dissected adults and literature (VANDEL 1962, Araujo et al. 1996) was used for comparisons.

Revista Brasileira de Zoologia 24 (2): 493-502, junho 2007 


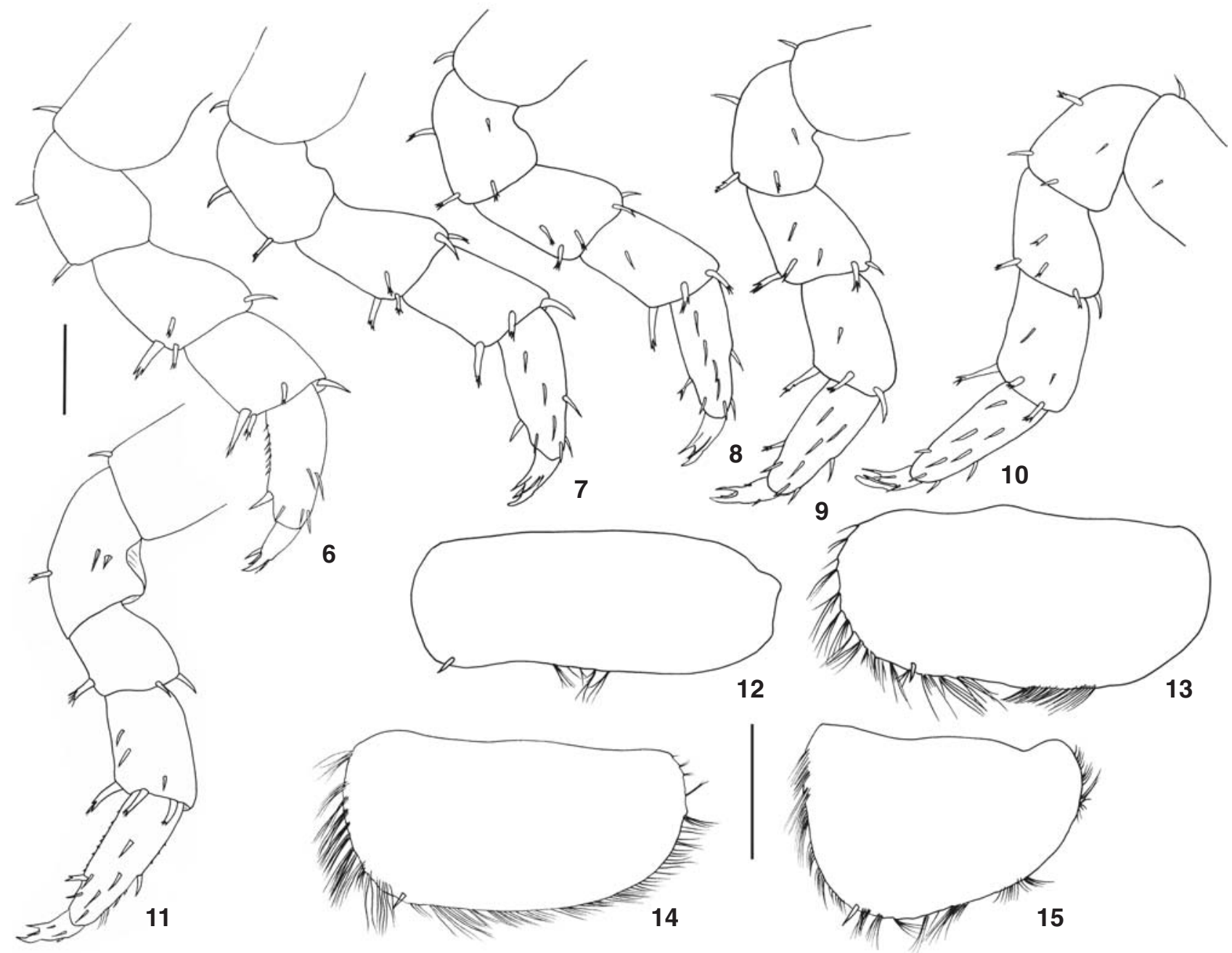

Figures 6-15. Porcellio dilatatus manca I: (6) pereiopod I; (7) pereiopod II; (8) pereiopod III; (9) pereiopod IV; (10) pereiopod V; (11) pereiopod VI; (12) exopod of pleopod II; (13) exopod of pleopod III; (14) exopod of pleopod IV; (15) exopod of pleopod V. Scale: $0.1 \mathrm{~mm}$.

\section{RESULTS}

\section{Manca I}

Color. At birth, individuals are not pigmented, but present rare spare granules of dark pigments, generally on the lateral margins of pereionites. The unpigmented appearance is accentuated by the absence of food in the gut.

Cephalothorax. Frontal lobes: rudimentary, without the characteristic prominence of the adult. Eyes: five ommatidia. Antennula: tri-articulate with two apical aesthetascs; expansion of the distal article forming a small shield at the base of aesthetascs (Fig. 1). Antenna: apical organ almost half the length of distal flagellar article; proximal article twice the length of the distal article; peduncular articles present sparse tricorn-like setae (Fig. 2). Mandible: left mandible with two penicils, and right mandible with one penicil and one plumose seta. Maxillula: endite with
(4+6) teeth (four bifid); setal tufts on the lateral margin (Fig. 3). Maxilla: three medial setae on the apical portion between the lateral and medial lobes; several setae on the apical region of medial lobe (Fig. 4). Maxilliped: palp with apical setal tuft, inner setal set with a long and a short seta, medial tuft with three setae, endite with two prominent tooth on the medial distal margin (Fig. 5).

Pereion. Glandular fields absent; sparse tricorn-like setae; coxal plates with rounded latero-posterior margin; pereonite VII feebly developed. Pereiopods (Figs 6-11): pereiopod I with antennal-grooming brush extending to merus; all pereiopods with sparse setae presenting from simple to quadrifid tip; pereiopod VII absent.

Pleon. Pleonite I rudimentary; pleopod I absent; exopod of pleopods II-V with one seta and setal tufts on the distal margin (Figs 12-15).

Revista Brasileira de Zoologia 24 (2): 493-502, junho 2007 


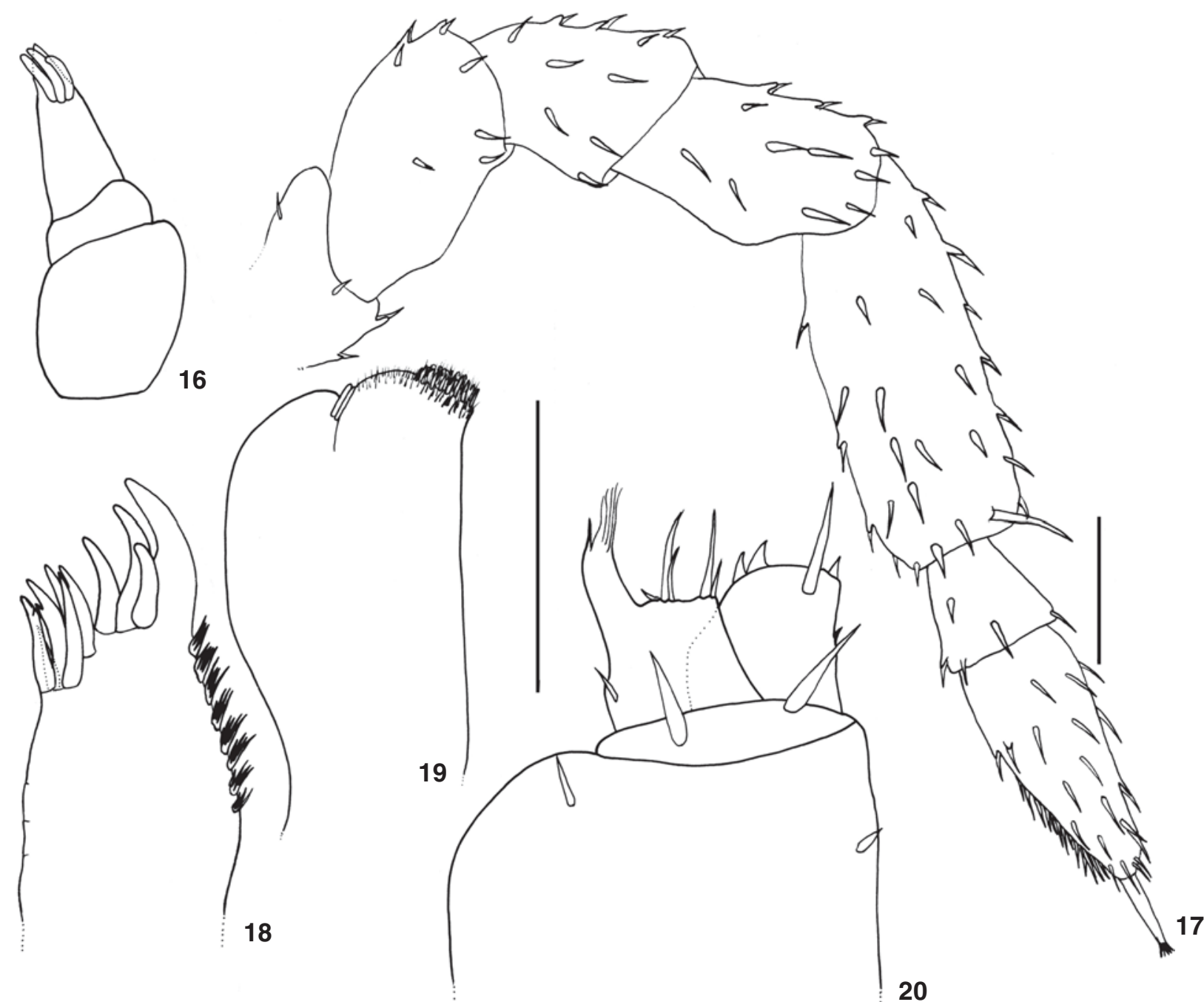

Figures 16-20. Porcellio dilatatus manca II: (16) antennulla; (17) antenna; (18) maxillula; (19) maxilla; (20) maxilliped. Scales: 16, 18-20 $=0.1 \mathrm{~mm} ; 17=0.1 \mathrm{~mm}$.

\section{Manca II}

Color. More pigment granules as compared to M I, but still maintains the unpigmented appearance; food can be seen in the gut. Unpigmented pereiopods and pleopods.

Cephalothorax. Frontal lobes: present, although not yet fully developed. Eyes: seven ommatidia (two developing ommatidia). Antennula: three apical aesthetascs (Fig. 16). Antenna: distal article with more than twice the length of the proximal article; higher number of setae as compared to M I (Fig. 17). Mandible: similar to M I, but with higher degree of sclerotization of the incisor process. Maxillula: similar to M I, higher number of lateral setae (Fig. 18). Maxilla: similar to M I; number of setae; lateral and medial lobe present the same size (Fig. 19). Maxilliped: more developed setae (Fig. 20).

Revista Brasileira de Zoologia 24 (2): 493-502, junho 2007
Pereion. Glandular fields slightly developed. Pereionite VII more developed than in M I, with small coxal plates. Pereiopods: all pereiopods present a higher number of setae as compared to M I (Figs 21-26). Beginning of development of pereiopod VII, which is found ventrally folded under the sixth and seven pereionites; no distinguishable articles at this stage (Fig. 50).

Pleon. Pleopod I absent; exopod of pleopod II with one seta; pleopods III and IV with five setae; pleopod V with five to six setae (Figs 27-30).

\section{Manca III}

Color. Similar to M II, although with a higher degree of pigmentation, which can greatly vary among individuals.

Cephalothorax. Frontal lobes: present and prominent, similar to adult. Eyes: eight ommatidia. Antennula: similar to $\mathrm{M}$ 

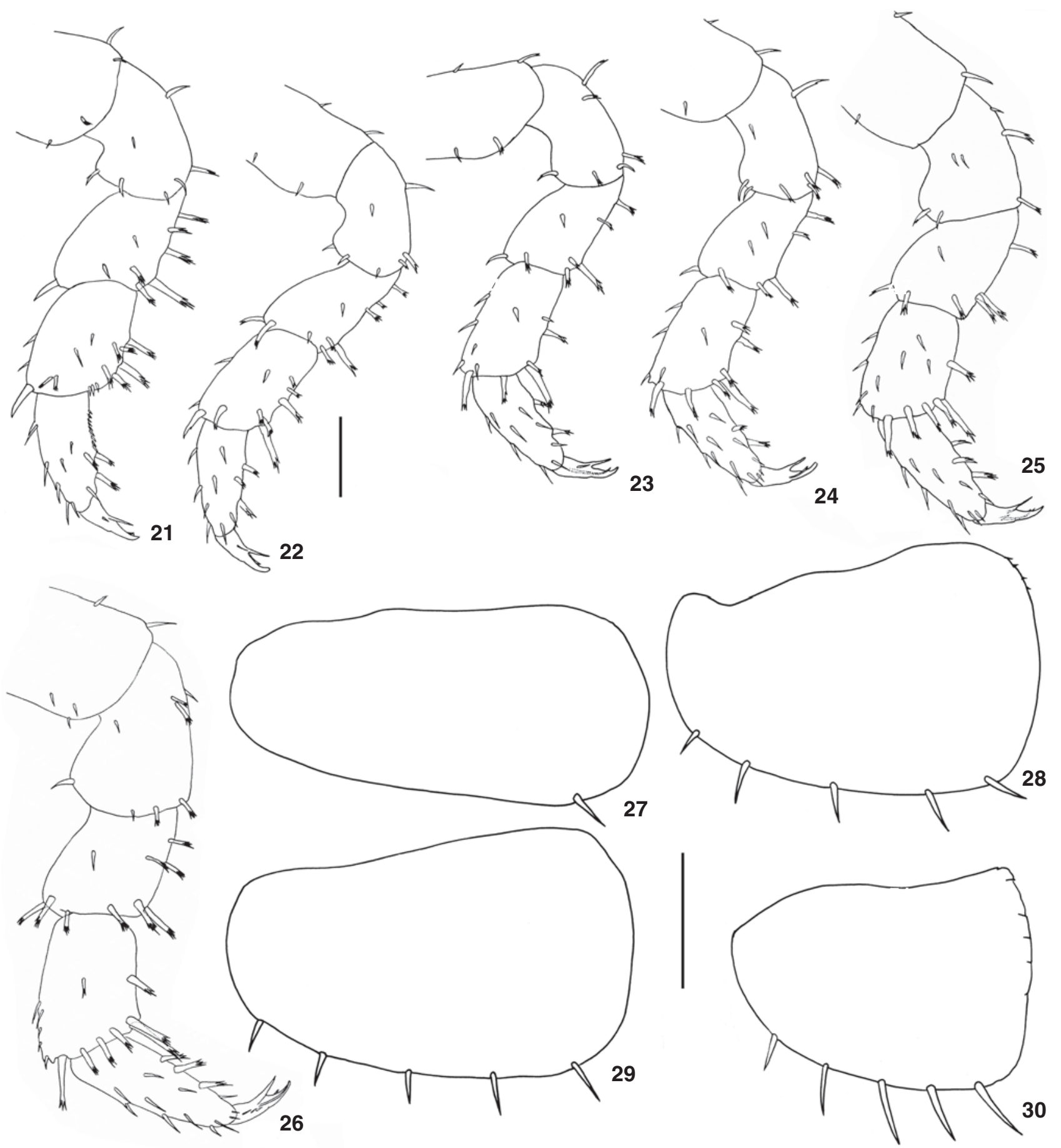

Figures 21-30. Porcellio dilatatus manca II: (21) pereiopod I; (22) pereiopod II; (23) pereiopod III; (24) pereiopod IV; (25) pereiopod V; (26) pereiopod VI; (27) exopod of pleopod II; (28) exopod of pleopod III; (29) exopod of pleopod IV; (30) exopod of pleopod V. Scale: $0.1 \mathrm{~mm}$.

I (Fig. 31). Antenna: similar to M II (Fig. 32). Mandible: similar to adults. Maxillula: similar to adults (Fig. 33). Maxilla: medial lobe wider than lateral lobe; higher density of small and cuspi- date setae (Fig. 34). Maxilliped: similar to adults (Fig. 35).

Pereion. Glandular fields similar to M II. Pereiopods more setose than M II (Figs 36-41). Pereonite VII almost fully devel- 


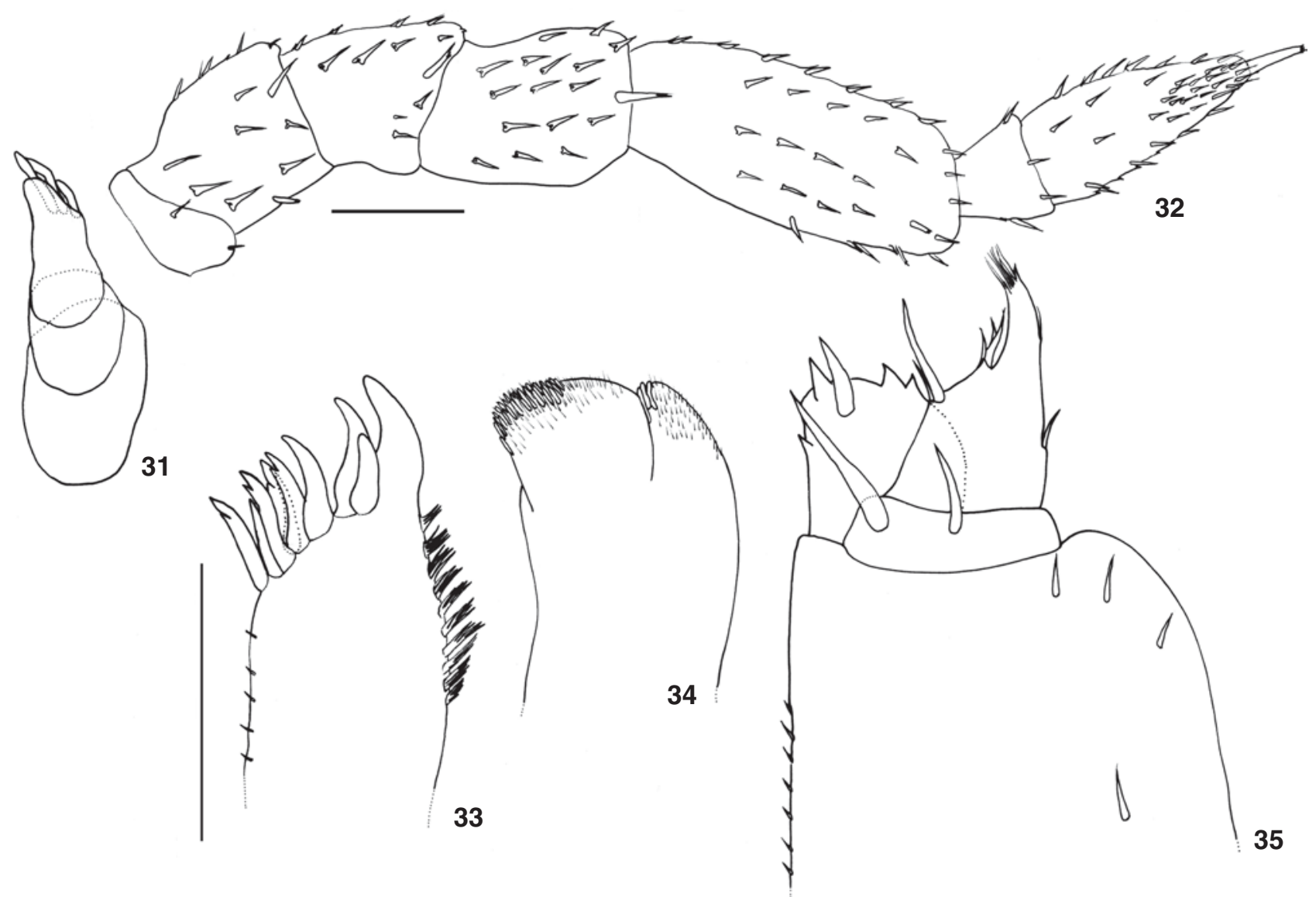

Figures 31-35. Porcellio dilatatus manca III. (31) antennulla; (32) antenna; (33) maxillula; (34) maxilla; (35) maxilliped. Scales: 31,33-35 $=0.1 \mathrm{~mm} ; 32=0.1 \mathrm{~mm}$.

oped; visible coxal plates; pereiopod VII more developed, ventrally folded under the sixth and seventh pereionites; all articles distinct (Fig. 51).

Pleon. Pleonites similar to M II. Exopod of pleopod II with one seta; pleopods III-V with seven setae (Figs 42-45).

The main distinguishing characteristics of the manca stages include the morphology of the antennula, antennal flagellum, pereiopod VII, setae of pleopods and number of ommatidia (Tab.
I). The width of the cephalothorax of manca stages varied from $0.50 \mathrm{~mm}$ to $0.75 \mathrm{~mm}$ (Tab. II). There were size overlaps among all the stages. The intermolt period is similar in M II and MIII, being 11 to 14 days, and 12 to 13 days, respectively (Tab. II).

\section{DISCUSSION}

Ecdysis in $P$. dilatatus is biphasic as with the other isopods. It is similar to the process described by Araujo et al. (2004),

Table I. Porcellio dilatatus. Summary of characteristics of each manca stage.

\begin{tabular}{|c|c|c|c|c|c|}
\hline Stage & $\begin{array}{l}\text { Eyes (number } \\
\text { of ommatidia) }\end{array}$ & Antennula & Antenna: flagellum & Pereiopod VII & Exopod of pleopods III-V \\
\hline $\mathrm{Ml}$ & 5 & $\begin{array}{l}\text { With two apical } \\
\text { aesthetascs }\end{array}$ & Proximal article is the largest & Absent & $\begin{array}{l}\text { Distal margin with one seta } \\
\text { and tufts of fine setae }\end{array}$ \\
\hline MII & 7 & $\begin{array}{l}\text { With three apical } \\
\text { aesthetascs }\end{array}$ & Distal article is the largest & $\begin{array}{l}\text { Bent in ventral pereion; } \\
\text { articles not distinct }\end{array}$ & Distal margin with $5-6$ setae \\
\hline MIII & 8 & $\begin{array}{l}\text { With three apical } \\
\text { aesthetascs }\end{array}$ & Distal article is the largest & $\begin{array}{l}\text { Bent in ventral pereion; } \\
\text { all articles distinct }\end{array}$ & Distal margin with 7 setae \\
\hline
\end{tabular}

Revista Brasileira de Zoologia 24 (2): 493-502, junho 2007 


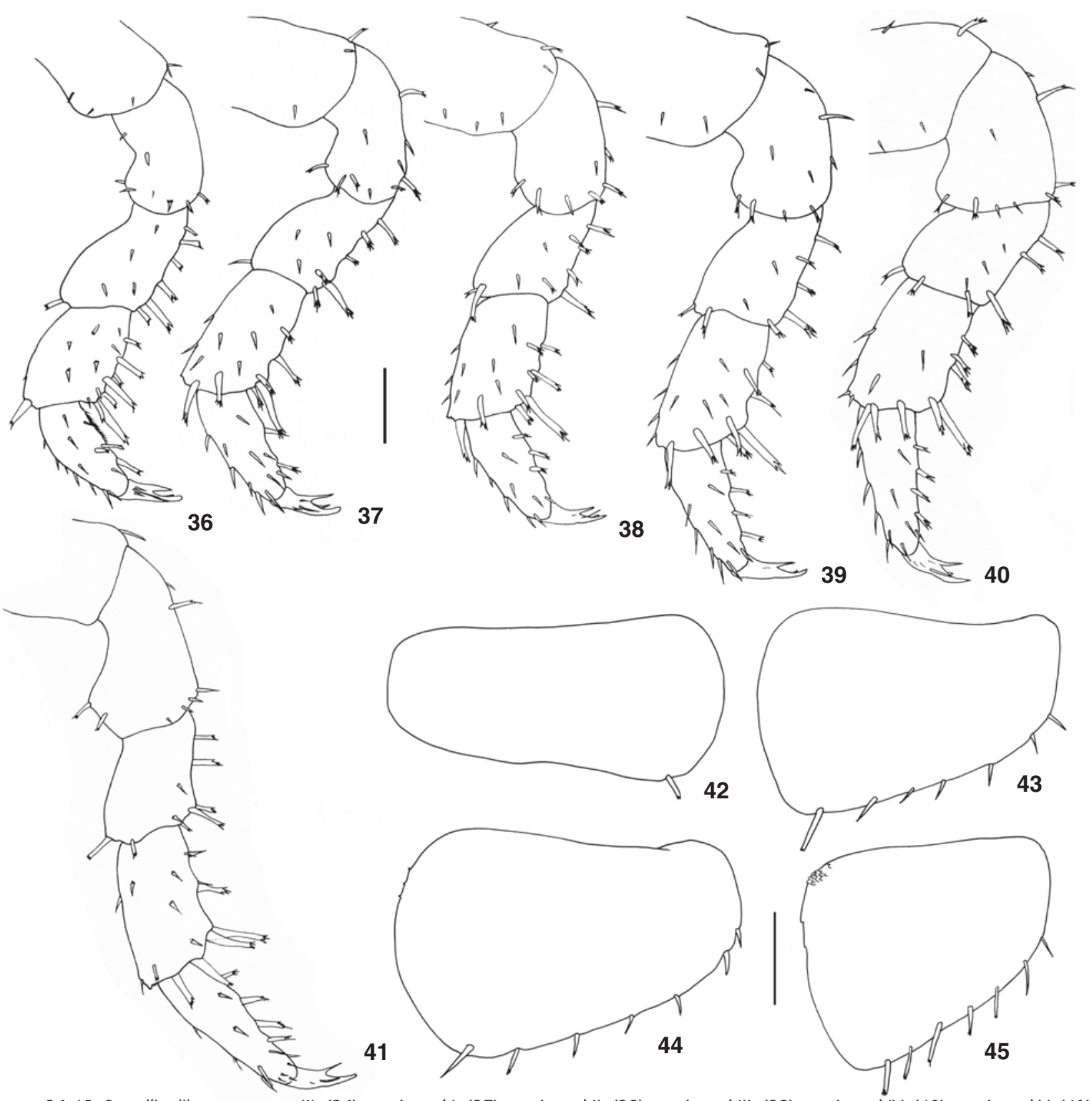

Figures 36-45. Porcellio dilatatus manca III: (36) pereiopod I; (37) pereiopod II; (38) pereiopod III; (39) pereiopod IV; (40) pereiopod V; (41) pereiopod VI; (42) exopod of pleopod II; (43) exopod of pleopod III; (44) exopod of pleopod IV; (45) exopod of pleopod V. Scale: $0.1 \mathrm{~mm}$.

Table II. Porcellio dilatatus. Mean \pm SD of the cephalotorax width and duration of each manca stage (sample size in parentheses).

\begin{tabular}{ccc}
\hline Stage & Cephalotorax width $(\mathrm{mm})$ & Stage duration \\
\hline MI & $0.609 \pm 0.028(50)$ & $18.7 \pm 1.5$ hours $(52)$ \\
MII & $0.669 \pm 0.032(50)$ & $12.7 \pm 1.19$ days $(101)$ \\
MIII & $0.704 \pm 0.023(34)$ & $12.7 \pm 0.45$ days $(24)$ \\
\hline
\end{tabular}

but in this species, maximum time to complete posterior or anterior molt may be longer than 15 minutes, and in some cases, more than 30 minutes.

In $P$. dilatatus, the first molt occurs less than one day after birth. During this period mancas do not feed, as evidenced by the absence of food in the gut. Overall, the period of the first molt does not exceed 24 hours (HeELey 1941, HADDAD 1982,

Revista Brasileira de Zoologia 24 (2): 493-502, junho 2007 

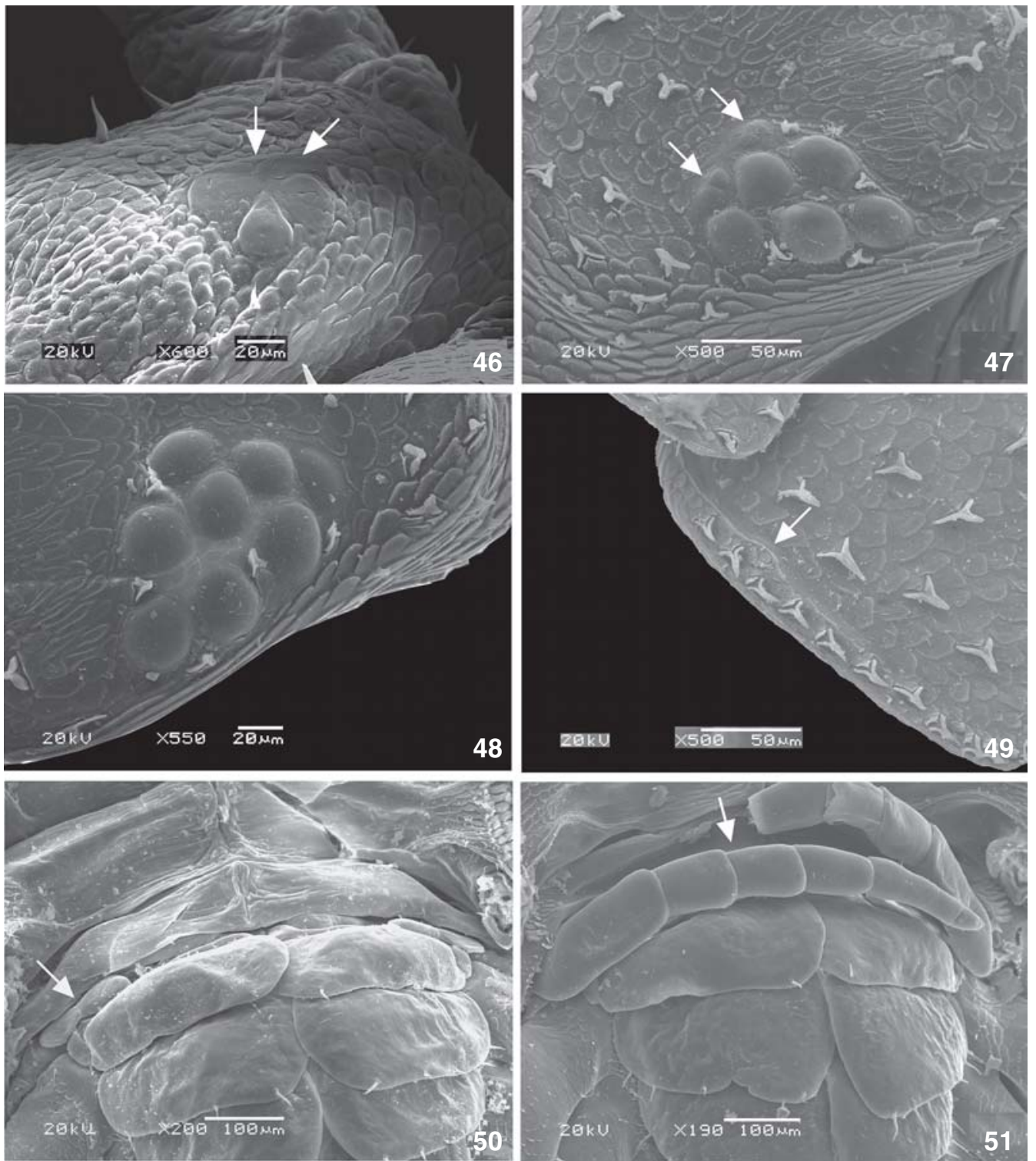

Figures 46-51. Porcellio dilatatus: (46) compound eye of manca I. The white arrows indicate ommatidia; (47) compound eye of manca II. The white arrows indicate ommatidia in development; (48) compound eye of manca III; (49) coxal plate, pereionite IV of manca II. The white arrow indicates the region of the glandular field; (50) manca II; pleon in ventral view. The white arrow indicates the seventh pereiopod without distinction of the articles; (51) manca III; pleon in ventral view. The white arrow indicates the seventh pereiopod with all articles already distinct.

Araujo et al. 2004), with the exception of Hemilepistus reaumurii (Milne-Edwards, 1840), a species that inhabits arid and semiarid environments and which the period between birth and the first molt varies from 24 to 48 hours (KACEM-LACHKAR 1997).

The general pattern is a progressive increase in the number of setae and pigment density throughout development. This can be observed in the general aspect of the body and of the appendages, being the antennae a good example.

Revista Brasileira de Zoologia 24 (2): 493-502, junho 2007
M I can be easily distinguished by the size of the articles of the antennal flagellum; the proximal article is longer than the distal one. During the subsequent stages, there is an inversion of the relative size of these articles, a pattern observed in other species (Verhoeff 1920, Matsakis 1955, Araujo et al. 2004). In addition to the absence of the seventh pair of pereiopods and empty gut, this is also an easily distinguishable characteristic of M I. Eyes consist of five ommatidia with distinct morphology, 
with a flattened dorsoventral aspect (Fig. 46), contrasting with the globular shape in M II and M III. Developing ommatidia were observed in M II (Fig. 47). M III has one additional ommatidia when compared to the preceding stage (Fig. 48).

Frontal lobes become gradually prominent during development, and their aspect is similar to that of adults in MII. Glandular field areas, although feebly developed, can be observed in M II (Fig. 49), and these structures are not significantly different in M III.

Mouth pieces in M I are similar to those in other manca stages as well as in adults. Nevertheless, the maxillae acquire the typical proportion between medial and lateral lobes only in M III. The degree of sclerotization and mechanical resistance of these appendages is reduced, particularly in $\mathrm{M} \mathrm{I}$, which may be associated with the short period they spent out of the marsupium without feeding. The appendages involved in food fragmentation in M II, such as maxillulae teeth and mandible incisor process, are more sclerotized. From this stage, mancas are capable of feeding, as indicated by the gut content.

Pereiopods show pattern similar to adults, including the presence of the antennal-grooming brush in $\mathrm{M} \mathrm{I}$. The number of tricorn-like setae increases from M I to M III. The absence of setae on proximal portion of ischium in all pereipods is also a distinct characteristic of M I. The different degree of development of the seventh pair of pereiopods in all manca stages constitutes a good diagnostic feature. It is absent in M I, it is folded under the abdomen and shows no article differentiation in M II, which only occurs in M III.

A remarkable characteristic, which was not previously observed in terrestrial isopods, is the tufts of setae on the distal margin of pleopod exopods in M I. These structures may constitute an adaptation to life inside the marsupium, as they are absent in the subsequent stages. The implication of this characteristic in Oniscidean phylogeny (SCHMALFuss 1989, ERHARD 1998) especially within the Crinocheta (MATTERN 2003) is a matter of future discussion. The number of setae on the distal margin of exopods III to $\mathrm{V}$ is a distinctive characteristic among the three stages. They present one, five to six and seven setae in MI, MII, and MIII, respectively.

The average intermolt period obtained in the present study is different from that observed by Heeley (1941), and may be related to differences at population level or in rearing methods. In P. dilatatus, the development time from birth to second molt is approximately 26 days, whereas in other species, such as Atlantoscia floridana (van Name, 1940) and Armadillidium vulgare (Latreille, 1804), it is around 21 (Araujo et al. 2004) and 22 days (Heeley 1941), respectively.

\section{ACKNOWLEDGEMENTS}

The authors thank CNPQ for the undergraduate scientific grant (PIBIC) to P.E.D.B, FAPERGS (PROAPP, Proc. 0409925) for financial support, and Daniel Sanpedro for his help in rearing the first animals obtained in this study. This is contribution number 521 of the Department of Zoology.

\section{REFERENCES}

Araujo, P.B.; A.F. Quadros; M.M. Augusto \& G. Bond-Buckup. 2004. Postmarsupial development of Atlantoscia floridana (van Name, 1940) (Crustacea, Isopoda, Oniscidea): sexual differentiation and size at onset of sexual maturity. Invertebrate Reproduction and Development 45 (3): 221-230.

Araujo, P.B.; L. Buckup \& G. Bond-Buckup. 1996. Isópodos terrestres (Crustacea, Oniscidea) de Santa Catarina e Rio Grande do Sul, Brasil. Iheringia (81): 111-138.

Araujo, P.B.; M.M. Augusto \& G. Bond-Buckup. 2004. Postmarsupial development of Atlantoscia floridana (van Name, 1940) (Crustacea, Isopoda, Oniscidea): the manca stages. Journal of Natural History 38: 951-965.

ERHARD, F. 1998. Phylogenetics relationships within the the Oniscidea (Crustacea, Isopoda). Israel Journal of Zoology 44: 303-309.

Haddad, M.A. 1982. Estádios do crescimento pósmarsupial de Balloniscus sellowii (Brandt, 1833) (Isopoda, Oniscoidea). Dusenia 13 (3): 135-143.

Heeley, W. 1941. Observations on the life of some terrestrial isopods. Proceedings of the Zoological Society of London 111 (B): 79-119.

Helden, A.J. \& M. Hassall. 1998. Phenotypic plasticity in growth and development rates of Armadillidium vulgare (Isopoda: Oniscidea). Israel Journal of Zoology 44: 379-394.

Hoese, B. 1984. The marsupium in terrestrial isopods, p. 65-76. In: S.L. SuTTON \& D.M. Holdich (Eds). The biology of terrestrial isopods. Symposium of the Zoological Society of London, vol. 53, 520p.

Hoese, B. \& H.H. JANSSEN. 1989. Morphological and physiological studies on the marsupium in terrestrial isopods. Monitore Zoologico Italiano 4: 153-173.

HopkIN, S. P. 1991. A Key to the Woodlice of Britain and Ireland. London, AIDGAP.

Kacem-Lachkar, H. 1997. Étude du développement post-embrionnaire d'Hemilepistus reamuri (Audouin, 1826) (Isopoda, Oniscidea). Crustaceana 70 (5): 513-526.

Leistikow, A. \& P.B. Araujo 2001. Morphology of respiratory organs in South American Oniscidea ("Philosciidae"), p. 329336. In: B. Kensley \& R.C. BRusca (Eds). Crustacean Issues. Rotterdam, Balkema, vol. 13, 357p.

Lemos De CASTRo, A. 1971. Isópodos terrestres introduzidos no Brasil. Boletim do Museu Nacional, Nova Série, Zoologia (282): 1-14.

Mattern, D. 2003. New aspects in the phylogeny of the Oniscidea inferred from molecular data. Crustaceana Monographs 2: 23-37.

Matsakis, J. 1955. Contribution a l'etude du développement postembryonnaire et de la croissance des Oniscoides. Bulletin de la Societé Zoologique de la France 80: 52-65.

Schmalfuss, H. 1989. Phylogenetics in Oniscidea. Monitore Zoologico Italiano 4: 3-27.

Schmalfuss, H. 2003. World catalogue of terrestrial isopods 
(Isopoda: Oniscidea). Stuttgarter Beiträge zur Naturkunde Serie A (Biologie) 654: 1-341.

Tomescu, N. \& C. Craciun. 1987. Postembryonic ontogenetic development in Porcellio scaber (Crustacea: Isopoda). Pedobiologia 30: 345-350.

VANDEL, A. 1943. Essai sur l'origine, l' evolution et la classification des Oniscoïdes (Isopodes terrestres). Bulletin Biologique de la France et de la Belgique 30 (Suppl.): 1-36.

VANDel, A. 1962. Isopodes Terrestres (Deuxième partie). In: Fau- ne de France. Paris, P. Lechevalier, vol. 66, p. 417-931.

VerhoefF, K.W. 1920. Zur Kenntnis der Larven, des Brutsackes und der Bruten der Oniscoidea. Zoologische Anzeiger 51: 169-189.

Zidar, P.; D. Drobne \& J. Strus. 1998. Determination of moult stages of Porcellio scaber (Isopoda) for routine use. Crustaceana 72: 1-9.

ZiMMER, M. \& W. Topp. 1998. Nutritional biology of terrestrial isopods (Isopoda: Oniscidea): copper revisited. Israel Journal of Zoology 44: 473-486.

Received in 30.XI.2006; accepted in 05.VI.2007. 